\title{
Ethyl Acetate Fraction from Trichilia catigua Confers Partial Neuroprotection in Components of the Enteric Innervation of the Jejunum in Diabetic Rats
}

\author{
Cynthia Priscilla do Nascimento Bonato Panizzon ${ }^{a}$ \\ Marcílio Hubner de Miranda Neto ${ }^{a}$ Francielle Veiga Ramalho ${ }^{a}$ Renata Longhini ${ }^{b}$ \\ João Carlos Palazzo de Mello ${ }^{b}$ Jacqueline Nelisis Zanonia \\ aDepartment of Morphological Sciences, Universidade Estadual de Maringá, Paraná, Brasil, 'Laboratory \\ of Pharmaceutical Biology, Palafito, Universidade Estadual de Maringá, Paraná, Brasil
}

\section{Key Words}

Trichilia catigua • Enteric Neuron • Enteric Glia • Diabetes mellitus • Antioxidant action • Neuroprotection

\begin{abstract}
Background/Aims: Diabetes causes damage to the enteric nervous system. The enteric nervous system consists of neurons and enteric glial cells (EGCs). The present study evaluated the effects of an ethyl-acetate fraction (EAF) from Trichilia catigua (T. catigua; $200 \mathrm{mg} / \mathrm{kg}$ ) on the total population of enteric neurons (HuC/D-immunoreactive [IR]) and EGCs (S100-IR and glial fibrillary acidic protein [GFAP]-IR) in the total preparation and jejunal mucosa in diabetic rats. Methods: The animals were distributed into four groups: normoglycemic rats $(N)$, diabetic rats (D), normoglycemic rats that received the EAF (NC), and diabetic rats that received the EAF (DC). The jejunum was processed for immunohistochemistry to evaluate HuC/D, S100, and GFAP immunoreactivity. The expression of S100 and GFAP proteins was also quantified by Western blot. Results: The D group exhibited a decrease in the number of neurons and EGCs, an increase in the area of cell bodies, an increase in $\mathrm{S} 100$ protein expression, a decrease in GFAP protein expression, and a decrease in S100-IR and GFAP-IR EGCs in the jejunal mucosa. The DC group exhibited a decrease in the number of neurons and EGCs, a decrease in the area of cell bodies, a decrease in S100 and GFAP protein expression, and a decrease in S100-IR and GFAP-IR EGCs in the jejunal mucosa. The NC group exhibited maintenance of the number of neurons and EGCS, an increase in the area of cell bodies, and a decrease in S100 and GFAP protein expression. Conclusion: The EAF from T. catigua partially conferred protection against diabetic neuropathy in the enteric nervous system.
\end{abstract}




\section{Cellular Physiology Cell Physiol Biochem 2019;53:76-86 and Biochemistry \begin{tabular}{l|l} 
DOl: 10.33594/000000122 & (c) 2019 The Author(s). Published by \\
Cell Physiol Biochem Press GmbH\&Co. KG
\end{tabular} \\ Do Nascimento Bonato Panizzon et al.: Trichilia Catigua Confers Partial Neuroprotection in the Enteric Nervous System}

\section{Introduction}

Diabetic neuropathy is the most common complication of diabetes. Approximately half of diabetic patients present symptoms of this disorder [1]. Many mechanisms have been proposed to explain neuronal dysfunction and degeneration in diabetic nerves, including impairments in fatty acid metabolism [2], the production of advanced glycation end products [3], a reduction of nerve blood flow [4], activation of the polyol pathway [5], and deficiencies in neurotrophic substances [6]. The result of all of these factors is the overproduction of reactive oxygen species (ROS). When ROS production exceeds antioxidant capacity, oxidative stress occurs. If cellular antioxidants do not scavenge free radicals, then such radicals can attack and damage proteins, lipids, and nucleic acids in the cell. When this occurs, biological activity decreases, leading to losses of energy metabolism, cell signaling, transport, and other principal functions. These altered products are also targeted for proteasome degradation, further decreasing cellular function. The accumulation of such injury can ultimately cause a cell to die through necrotic or apoptotic mechanisms [7].

Patients with diabetes mellitus (DM) present disorders of the gastrointestinal tract, such as esophageal enteropathy, gastroparesis, constipation, diarrhea, and fecal incontinence [1]. These symptoms are related to damage to the enteric nervous system (ENS). The ENS consists of enteric neurons and enteric glial cells (EGCs) [8]. Enteric glial cells were previously viewed as only a mechanical support structure for neurons. More recently, however, they have been shown to have other important functions to maintain intestinal homeostasis. Enteric glial cells have been shown to play an essential role in regulating the intestinal barrier and influencing motility and inflammatory processes [9-12]. Some studies have shown that both EGCs and enteric neurons are affected by diabetes $[11,13,14]$. Many studies have sought to verify the action of antioxidants (e.g., quercetin, vitamin E, vitamin C, L-glutamine, and L-glutathione) in diabetic neuropathies [14-18]. The present study evaluated the effects of an ethyl-acetate fraction (EAF) from Trichilia catigua, which has been reported to exert better antioxidant effects than the crude extract [19]. Previous studies have investigated the antioxidant activity of natural products for the treatment of DM [20-22]. A few studies have evaluated the antioxidant effects of natural products on diabetic neuropathy in the ENS. Thus, the objective of the present study was to evaluate the effects of the EAF from T. catigua on the total population of enteric neurons (HuC/D-immunoreactive [IR]) and EGCs (S100-IR and glial fibrillary acidic protein [GFAP]-IR) in the jejunum in diabetic rats.

\section{Materials and Methods}

All of the experimental procedures were conducted according to the ethical principles of the Brazilian Society of Animal Laboratory Science (SBCAL/COBEA). These procedures were approved by the Committee of Ethics in Animal Experimentation of the Universidade Estadual de Maringá (protocol no. 082/2012).

\section{Plant material and extract preparation}

The crude extract was prepared from the powdered bark of T. catigua (HUEM exsiccate no. 1943) as described by Dos Santos et al. [23] and Gomes et al. [24]. The crude extract (50 g) was dissolved in water $(500 \mathrm{ml})$ and extracted with ethyl acetate $(500 \mathrm{ml})$. Afterward, both fractions were concentrated in vacuo and lyophilized, yielding the EAF (8.2 g) and aqueous fraction according to Chassot et al. [19] and Longhini et al. [25]. The EAF was prepared and supplied by PALAFITO (Laboratory of Pharmaceutical Biology) under the supervision of Prof. Dr. João Carlos Palazzo de Mello.

The EAF was evaluated by measurements of procyanidin B2 and epicatechin by high-performance liquid chromatography (HPLC) according to Longhini et al. [25]. The EAF (5 mg) was weighed and dissolved in $1 \mathrm{ml}$ of $20 \%$ aqueous methanol solution. This solution was eluted in a solid-phase extraction (SPE; Strata C18-E, Phenomenex, $200 \mathrm{mg} / 3 \mathrm{ml}$ ), preconditioned with methanol and water. A $20 \%$ aqueous methanolic solution was added to a volumetric flask to achieve a final volume of $10 \mathrm{ml}$. 


\section{Cellular Physiology Cell Physiol Biochem 2019;53:76-86 \\ \begin{tabular}{l|l} 
DOI: 10.33594/000000122 & (c) 2019 The Author(s). Published by
\end{tabular} \\ and BIOChemistry Published online: 14 June $2019 \quad$ Cell Physiol Biochem Press GmbH\&Co. KG \\ in the Enteric Nervous System}

The sample was analyzed by HPLC under the following conditions: Thermo device equipped with a PDA spectrophotometer detector (Finnigan Surveyor PDA Plus Detector), integral pumps and degasser (Finnigan Surveyor LC Pump Plus), automatic sampler (Finnigan Surveyor Autosampler Plus) equipped with a $10 \mu \mathrm{l}$ loop and software controller (Chromquest), Phenomenex $100 \AA$ Å column $(250 \times 4.6 \mathrm{~mm}, 5 \mu \mathrm{m})$ and precolumn ( $6 \times 3 \mathrm{~mm}, 5 \mu \mathrm{m}$, Phenomenex). The EAF that was used in the present study was from the same lot as the EAF that was used by Gomes et al. [24]. The procyanidin B2 and epicatechin concentrations were 74.4 and $40.6 \mathrm{mg} / \mathrm{g}$ EAF, respectively.

\section{Material collection and processing}

Twenty-four male Wistar rats (Central Vivarium of Universidade Estadual de Maringá) were randomly distributed into four groups: normoglycemic rats ( $\mathrm{N}$ group), diabetic rats (D group), normoglycemic rats that received the EAF (NC group), and diabetic rats that received the EAF (DC group). The rats were housed in individual cages for 120 days under a $12 \mathrm{~h} / 12 \mathrm{~h} \mathrm{light} /$ dark cycle and controlled temperature $\left(24^{\circ} \mathrm{C} \pm 2^{\circ} \mathrm{C}\right)$. Food and water were available ad libitum.

The animals in the D and DC groups underwent type 1 DM induction after a $14 \mathrm{~h}$ fast. Streptozotocin was administered intravenously ( $35 \mathrm{mg} / \mathrm{kg}$ body weight; Sigma, St. Louis, MO, USA) under anesthesia with thiopental ( $40 \mathrm{mg} / \mathrm{kg}$ body weight, i.p., Abbott Laboratories, Chicago, IL, USA). To verify the establishment of the experimental model of DM, 2 days after induction, one drop of blood was obtained from the tail of the animals to measure glucose photometrically based on glycoso-dye-oxidoreductase (Accu-Chek Active glycosimeter, Roche Diagnostics GmbH, Mannheim, Germany). Only rats with glycemia > $200 \mathrm{mg} / \mathrm{dl}$ were used in the subsequent experiments [16-18].

The EAF was administered daily in the NC and DC groups by gavage at a dose of $200 \mathrm{mg} / \mathrm{kg}$ [19] for 58 days. The animals in the $\mathrm{N}$ and $\mathrm{D}$ groups underwent the same administration schedule but received only the diluent.

At 150 days of age, the animals were weighed and received an intravenous injection of vincristine sulfate $(0.5 \mathrm{mg} / \mathrm{kg}$; Eurofarma Laboratórios, São Paulo, SP, Brazil) $2 \mathrm{~h}$ before euthanasia for microtubule stabilization. The rats were anesthetized with thiopental $(40 \mathrm{mg} / \mathrm{kg}$ body weight, i.p., Abbott Laboratories, Chicago, IL, USA). Blood was collected by cardiac puncture for blood glucose measurements using the glucose-oxidase method to confirm the diabetes. Laparotomy was performed, and the jejunum was collected.

For immunohistochemistry, whole mounts of the jejunum were washed in $0.1 \mathrm{M}$ phosphate-buffered saline (0.1 M PBS; pH 7.4), fixed for $18 \mathrm{~h}$ in Zamboni fixative solution [26], and stored at $4^{\circ} \mathrm{C}$. After fixation, the segments were opened along the mesenteric border and successively washed in $80 \%$ alcohol until complete removal of the fixative. Subsequent dehydration was performed with an ascending series of alcohol (95\% and 100\%), diaphanization in xylol, and rehydration in a descending series of alcohol $(100 \%$, $90 \%, 80 \%$, and $50 \%$ ). The samples were then stored in $0.1 \mathrm{MPBS}\left(\mathrm{pH} 7.4\right.$ ) with $0.08 \%$ sodium azide at $4^{\circ} \mathrm{C}$.

For the analysis of the mucosal layer, others samples were used to perform cryostat cuts. After fixation for $18 \mathrm{~h}$ in Zamboni fixative [26], the samples underwent successive washes in $0.1 \mathrm{M} \mathrm{PBS}$ (pH 7.4) for $12 \mathrm{~h}$, followed by cryoprotection in 18\% sucrose solution in $0.1 \mathrm{M} \mathrm{PBS}(\mathrm{pH} 7.4$ ) for $24 \mathrm{~h}$. After cryoprotection, the samples were soaking in O.C.T 4583 compound (Cryomatrix Shandon, Pittsburgh, PA, USA), rapidly frozen in liquid nitrogen, and stored at $-80^{\circ} \mathrm{C}$.

For Western blot, separate jejunum samples were collected and washed several times with KrebsRinger buffer solution ( $\mathrm{pH}$ 7.4) to completely remove the contents. Tissue lysis was performed in Turrax by immersion in homogenization buffer (50 mM Tris $\mathrm{HCl}$ [pH 7.2], $600 \mathrm{mM} \mathrm{NaCl}$, and $1 \mathrm{mM}$ EDTA) that contained protease inhibitor (Sigma-Aldrich, St. Louis, MO, USA). The lysed samples were then centrifuged for $10 \mathrm{~min}$ at $10,000 \mathrm{x} g$ to remove the insoluble portion. The supernatant was collected and stored at $-80^{\circ} \mathrm{C}$ until use. The concentration of total proteins in the supernatant was determined by the Bradford method (Bio-Rad, Hercules, CA, USA).

\section{Immunohistochemical double-staining for $\mathrm{HuC} / \mathrm{D}$ and $\mathrm{S} 100$ proteins}

The jejunum was cut into pieces $(\sim 1 \mathrm{~cm})$ that were then micro dissected to obtain whole-mount preparations to evaluate neurons in the myenteric plexus. To immunolabel HuC/D and S100 proteins, the tissue samples were first washed with $0.1 \mathrm{M}$ PBS (pH 7.4) with 0.5\% Triton (Sigma-Aldrich, St. Louis, MO, USA) twice for $10 \mathrm{~min}$. Following the washes, blockade was performed with $0.1 \mathrm{M} \mathrm{PBS} \mathrm{(pH} \mathrm{7.4)} \mathrm{and} 0.5 \%$ Triton X-100 with 2\% bovine serum albumin (BSA; Sigma-Aldrich, St. Louis, MO, USA) and 10\% goat serum 


\section{Cellular Physiology Cell Physiol Biochem 2019;53:76-86 \\ \begin{tabular}{l|l|l} 
DOI: 10.33594/000000122 & ( 2019 The Author(s). Published by
\end{tabular} \\ Published online: 14 June $2019 \quad$ Cell Physiol Biochem Press GmbH\&Co. KG \\ Do Nascimento Bonato Panizzon et al.: Trichilia Catigua Confers Partial Neuroprotection \\ in the Enteric Nervous System}

for $1 \mathrm{~h}$. To double-label HuC/D and S100, the whole mounts were incubated in a solution that contained both primary antibodies: mouse anti-HuC/D antibody (1:400 dilution; Molecular Probes, Eugene, OR, USA) and rabbit anti-S100 antibody (1:200 dilution; Sigma, St. Louis, MO, USA). After $72 \mathrm{~h}$ of incubation at room temperature, the jejunum was washed three times in $0.1 \mathrm{M}$ PBS (pH 7.4) that contained 0.5\% Triton X-100 (Sigma-Aldrich, St. Louis, MO, USA) for $5 \mathrm{~min}$ each and incubated for $4 \mathrm{~h}$ at room temperature with the following secondary antibodies: anti-mouse Alexa Fluor 488 (1:200 dilution; Molecular Probes, Eugene, OR, USA) and anti-rabbit Alexa Fluor 568 (1:200 dilution; Molecular Probes, Eugene, OR, USA). The whole mounts were washed three times in $0.1 \mathrm{M}$ PBS (pH 7.4) for 5 min each, mounted on slides with Prolong Gold Antifade mounting medium conjugated to DAPI (Molecular Probes, Eugene, OR, USA), and stored at $4^{\circ} \mathrm{C}$. For the negative control, the primary antibody was omitted. To avoid potential procedural variation, tissues from all groups of animals were stained at the same time using the same solutions.

\section{Quantitative analysis}

Quantification was performed by sampling in the intermediate jejunum region in images that were captured by microscopy with filters for immunofluorescence (Zeiss, Jena, Germany) and a high-resolution camera (Zeiss, Jena, Germany) coupled to a computer and later recorded on a flash drive. For each technique, 30 images/animal were captured with a 20x objective. All neurons and EGCs were quantified in each image. Quantification was performed using ImagePro Plus 4.5.0.29 image analysis software (Media Cybernetics, Silver Spring, MD, USA). The results are expressed as neurons and EGCs per $\mathrm{cm}^{2}$.

\section{Morphometric analysis}

Morphometric analyses of the total population of neurons (HuC/D-IR) and EGCs (S100-IR) were performed using samples of the myenteric plexus of the jejunum. The areas (in $\mu^{2}$ ) of 100 neuronal cell bodies and 100 EGCs were calculated per animal using ImagePro Plus 4.5.0.29 image analysis software (Media Cybernetics, Silver Spring, MD, USA).

\section{Immunohistochemical analysis of GFAP and S100 proteins in the mucosal layer}

The samples were semi-serially sectioned at $10 \mu \mathrm{m}$ using a cryostat, stretched on slides that were prepared with $2 \%$ organoacane adhesive in acetone, and stored at $-18^{\circ} \mathrm{C}$. The slides were washed three times with a solution that contained $0.5 \%$ Triton X-100 (Sigma-Aldrich, St. Louis, MO, USA) in 0.1 M PBS (pH 7.4) for 5 min each and blocked in a solution that contained 1\% BSA (Sigma-Aldrich, St. Louis, MO, USA) and 0.5\% Triton X-100 (Sigma-Aldrich, St. Louis, MO, USA) in $0.1 \mathrm{M} \mathrm{PBS} \mathrm{(pH} \mathrm{7.4)} \mathrm{for} 2 \mathrm{~h}$ at room temperature. The slides were then sequentially incubated in a humid chamber in a solution that contained 1\% BSA in 0.1 M PBS (pH 7.4) and 0.5\% Triton X-100 (Sigma-Aldrich, St. Louis, MO, USA) with the following primary antibodies for $72 \mathrm{~h}$ at $4^{\circ} \mathrm{C}$ : mouse anti-GFAP (1:200 dilution; Sigma-Aldrich, St. Louis, MO, USA) and rabbit anti-S100 (1:300 dilution; Sigma, St Louis, MO, USA). After incubation, the sections were washed three times with a solution that contained 0.5\% Triton X-100 (Sigma-Aldrich, St. Louis, MO, USA) in 0.1 M PBS (pH 7.4) for 5 min each. The sections were then incubated in a dark wet chamber in $2 \%$ BSA (SigmaAldrich, St. Louis, MO, USA) in 0.1 M PBS (pH 7.4) for $2 \mathrm{~h}$ at $4^{\circ} \mathrm{C}$. For slides that contained anti-GFAP primary antibody, Alexa Fluor 488 goat anti-mouse secondary antibody (1:200 dilution; Molecular Probes, Eugene, OR, USA) was added to the solution. For slides that contained anti-S100 primary antibody, Alexa Fluor 568 goat anti-rabbit secondary antibody (1:300 dilution; Molecular Probes, Eugene, OR, USA) was added to the solution. The sections were then washed in a solution that contained 0.5\% Triton X-100 (Sigma-Aldrich, St. Louis, MO, USA) in 0.1 M PBS (pH 7.4). The sections were mounted on slides with Prolong Gold Antifade mounting medium conjugated to DAPI (Molecular Probes, Eugene, OR, USA) and stored at $4^{\circ} \mathrm{C}$. For the negative control, the primary antibody was omitted. To avoid potential procedural variation, tissues from all groups of animals were stained at the same time using the same solutions.

\section{Quantitative analysis}

Quantification was performed using images that were captured with a microscope with filters for immunofluorescence and a high-resolution camera (Zeiss, Jena, Germany) coupled to a computer and later recorded using a flash drive. For each technique, 30 villi/animal were captured with a 20x objective and quantified. Quantification was performed using ImagePro Plus 4.5.0.29 image analysis software (Media Cybernetics, Silver Spring, MD, USA). 


\section{Cellular Physiology Cell Physiol Biochem 2019;53:76-86 \\ \begin{tabular}{ll|l} 
and Biol: $10.33594 / 000000122$ & & C 2019 The Author(s). Published by \\
Cell Physiol Biochem Press GmbH\&Co. KG
\end{tabular} \\ Do Nascimento Bonato Panizzon et al.: Trichilia Catigua Confers Partial Neuroprotection \\ in the Enteric Nervous System}

\section{Western blot}

Protein (30 $\mu \mathrm{g} /$ well) was separated using sodium dodecyl sulfate-polyacrylamide gel electrophoresis (17\% for S100 protein and 10\% for GFAP protein) and transferred to nitrocellulose membranes (Bio-Rad, Hercules, CA, USA). Transfer efficiency was verified by Ponceau-S staining (Sigma-Aldrich). Proteins were blocked for $1 \mathrm{~h}$ at room temperature with a solution that contained $5 \%$ nonfat dried milk and $0.1 \%$ Tween-20 in Tris-buffered saline (TBS) buffer (2.24 g/L Tris base and $8 \mathrm{~g} / \mathrm{L} \mathrm{NaCl}, \mathrm{pH} 7.6)$. The membranes were then incubated overnight at $4^{\circ} \mathrm{C}$ under stirring with rabbit anti-S100 primary antibody (1:500 dilution; Sigma, St Louis, MO, USA) and mouse anti-GFAP primary antibody (1:500 dilution; Sigma-Aldrich, St. Louis, MO, USA). The membranes were then incubated for $2 \mathrm{~h}$ at room temperature with horseradish peroxidase-conjugated anti-rabbit secondary antibody (1:1000 dilution; Novex, Ivintrogem Rockford, IL, USA) and horseradish peroxidase-conjugated anti-mouse secondary antibody (1:2000 dilution; Novex, Ivintrogem Rockford, IL, USA). Immunodetection was performed using the chemiluminescence method with a ChemiDoc MP imager according to the manufacturer's instructions (V3 Western Workflow, Bio-Rad, Hercules, CA, USA). Immunostaining was analyzed using Image Lab software (Bio-Rad, Hercules, CA, USA). Protein levels were normalized to $\beta$-actin as the control. All of the electrophoresis and Western blot protocols were performed according to the standard Bio-Rad Mini Protean System procedures.

\section{Statistical analysis}

The statistical analysis was performed using Statistics 7.0 software (Statsoft South America, Sao Caetano do Sul, SP, Brazil) and Prism 3.1 software (GraphPad, La Jolla, CA, USA). The results are expressed as mean \pm standard error of the mean. The morphometric data were subjected to delineation blocks followed by Fisher's test. The other data were analyzed using one-way analysis of variance (ANOVA) followed by Fisher's post hoc test. Values of $p<0.05$ were considered statistically significant.

\section{Results}

Sixty days after diabetes induction, the animals in the D and DC groups were determined to be hyperglycemic. Animals in the diabetic groups exhibited the loss of body weight compared with nondiabetic rats in the $\mathrm{N}$ and NC groups (Table 1).

The quantitative analysis revealed a reduction of the number of HuC/D-IR myenteric neurons $(p<0.0005)$ and S100-IR EGCs $(p<0.0001)$ in the D group compared with the N group. The administration of EAF in the DC group did not alter the reduction of the density of myenteric neurons or EGCs compared with the D group $(p>0.05)$. The NC group exhibited preservation of the number of HuC/D-IR neurons $(p<0.05)$ and S100-IR EGCs $(p<0.03)$ compared with the $\mathrm{N}$ group (Fig. 1).

The cell body area of HuC/D-IR neurons and S100-IR EGCs in diabetic animals increased by $24 \%$ and $39 \%$, respectively, in the D group compared with the $\mathrm{N}$ group $(p<0.00001$; Fig. 2 ). The EAF prevented the increase in the area of cell bodies of HuC/D-IR neurons and the area of cell bodies of S100-IR EGCs in diabetic animals (16\% and $12 \%$ respectively) in the DC group compared with the D group ( $p<0.00001$; Fig. 2$)$. Animals in the NC group exhibited a $13 \%$ increase in the area of HuC/D-IR neurons and 33\% increase in the area of S100-IR EGCs compared with the $\mathrm{N}$ group ( $p<0.00001$; Fig. 2 ).

$\mathrm{S} 100$ protein expression increased in diabetic animals compared with the $\mathrm{N}$ group ( $p$ $<0.03$; Fig. 3A). Treatment with the EAF in the DC group reduced S100 protein expression compared with the D group ( $p<0.01$; Fig. 3 ) but not compared with the $\mathrm{N}$ group ( $p>0.05$; Fig. 3). The expression of

Table 1. Physiological parameters, including initial weight (90 days old), final weight (150 days old), and final glycemia in the following groups: normoglycemic (N), diabetic (D), normoglycemic that received EAF (NC), and diabetic that received EAF (DC). The results are expressed as mean \pm SEM. $n=6$ rats/group. ${ }^{*} \mathrm{p}<0.05$, compared with $\mathrm{N}$ group

\begin{tabular}{lcccc}
\hline Physiological parameter & $\mathrm{N}$ & $\mathrm{NC}$ & $\mathrm{D}$ & $\mathrm{DC}$ \\
\hline Initial weight $(\mathrm{g})$ & $353.7 \pm 8.62$ & $358.3 \pm 13.04$ & $341.8 \pm 8.18$ & $362.0 \pm 9.90$ \\
Final weight $(\mathrm{g})$ & $455.3 \pm 18.38$ & $435.3 \pm 16.80$ & $326.8 \pm 1.74^{*}$ & $323.4 \pm 19.98^{*}$ \\
Final glycemia (mg/dl) & $121.2 \pm 12.23$ & $104.5 \pm 6.26$ & $565.8 \pm 23.12^{*}$ & $466.4 \pm 37.38^{*}$ \\
\hline
\end{tabular}




\section{Cellular Physiology Cell Physiol Biochem 2019;53:76-86 \\ \begin{tabular}{ll|l} 
DOl: 10.33594/000000122 & ( 2019 The Author(s). Published by \\
Cell Physiol Biochem Press GmbH\&Co. KG
\end{tabular} \\ Do Nascimento Bonato Panizzon et al.: Trichilia Catigua Confers Partial Neuroprotection in the Enteric Nervous System}

GFAP protein in the NC, D, and DC groups decreased compared with the N group ( $p>0.0003$; Fig. 3B).

The density of GFAP-IR EGCs in the jejunal mucosa decreased in the NC, D, and DC groups compared with the $\mathrm{N}$ group $(p<$ 0.05 ; Fig. 4A, C). The number of GFAP-IR EGCs was similar in the D and DC groups ( $p>0.05$; Fig. 4A). The density of S100-IR EGCs in the jejunal mucosa decreased in the D group compared with the $\mathrm{N}$ group $(p<0.05$; Fig. 4B, C). The density of S100-IR EGCs decreased in the D and DC groups compared with the NC group ( $p<0.05$; Fig. 4B, C), with no difference between the $D$ and DC groups ( $p>0.05$; Fig. 4B).

\section{Discussion}

The present study established a model of DM. The animals in the D and DC groups had a glycemic index $>400 \mathrm{mg} /$ $\mathrm{dl}$ and also presented significant weight loss at the end of the experiment. The results of this study were similar to previous studies that were performed by our research group $[14,16,18]$.

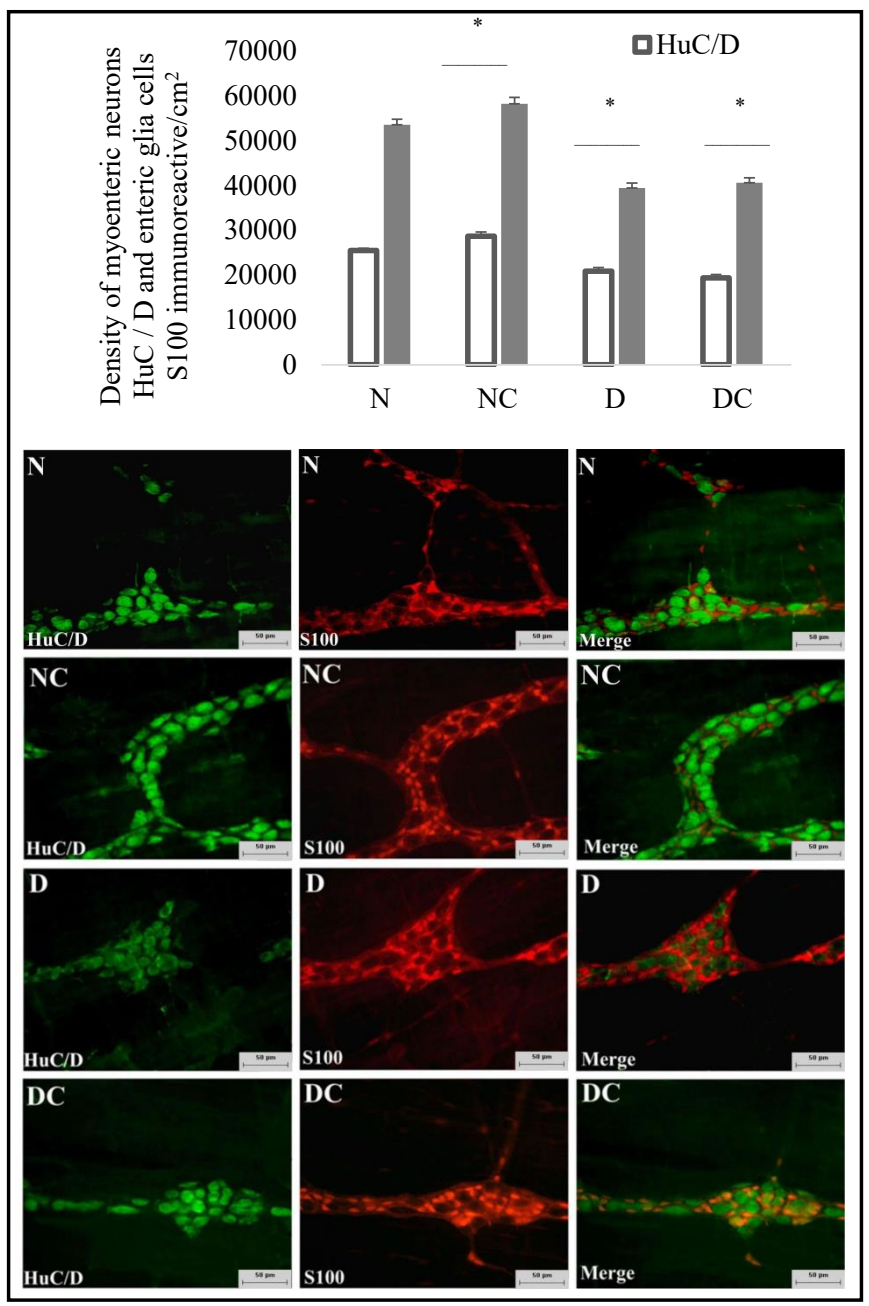

Fig. 1. (Top) Density per unit area $\left(\mathrm{cm}^{2}\right)$ of $\mathrm{HuC} / \mathrm{D}-$ immunoreactive myenteric neurons and S-100-immunoreactive enteric glial cells. The results are expressed as mean \pm SEM. ${ }^{*} \mathrm{p}<0.05$, compared with $\mathrm{N}$ group. (Bottom) Photomicrographs of $\mathrm{HuC} / \mathrm{D}$-immunoreactive myenteric neurons and $\mathrm{S}-100$ immunoreactive enteric glial cells in the jejunum in the N, NC, D, and DC groups. Scale bar $=50 \mu \mathrm{m} . \mathrm{n}=6$ rats/group.

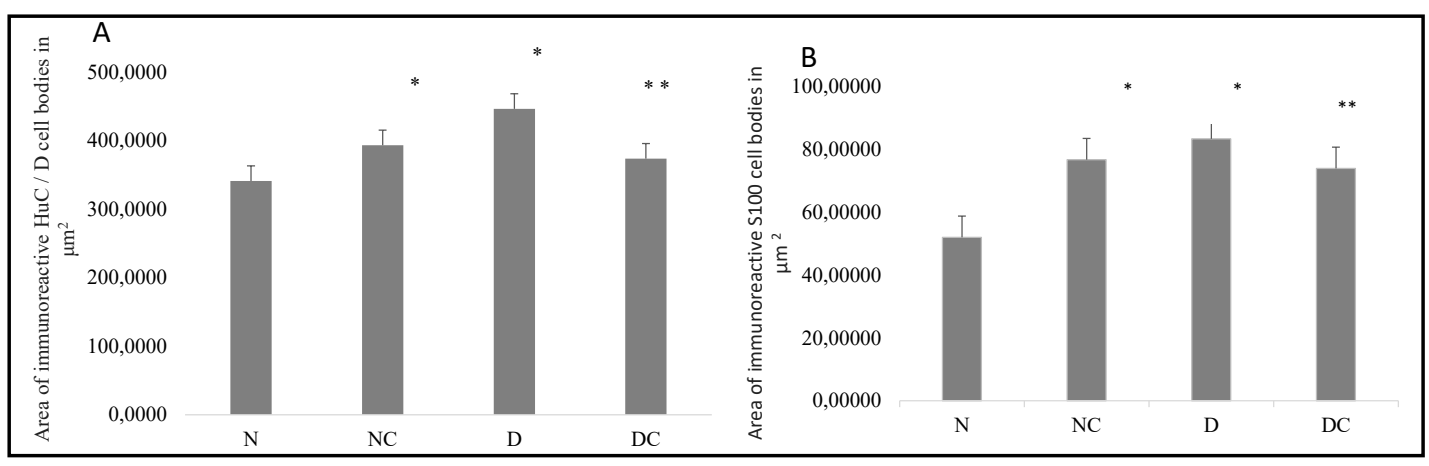

Fig. 2. (A, B) Cell body area $\left(\mu \mathrm{m}^{2}\right)$ of $\mathrm{HuC} / \mathrm{D}$-immunoreactive myenteric neurons (A) and $\mathrm{S}-100$ immunoreactive enteric glial cells (B) in the jejunum in the N, NC, D, and DC groups. The results are expressed as the mean \pm SEM. $n=6$ rats/group. ${ }^{*} \mathrm{p}<0.00001$, compared with the $\mathrm{N}$ group; ${ }^{* *} \mathrm{p}<0.00001$, compared with the D group. 


\section{Cellular Physiology Cell Physiol Biochem 2019;53:76-86}

\begin{tabular}{ll|l} 
and Biochemistry & $\begin{array}{l}\text { DOl: 10.33594/000000122 } \\
\text { Published online: } 14 \text { June } 2019\end{array}$ & $\begin{array}{l}\text { O 2019 The Author(s). Published by } \\
\text { Cell Physiol Biochem Press GmbH\&Co. KG }\end{array}$ \\
\cline { 2 - 3 } &
\end{tabular}

Do Nascimento Bonato Panizzon et al.: Trichilia Catigua Confers Partial Neuroprotection

in the Enteric Nervous System

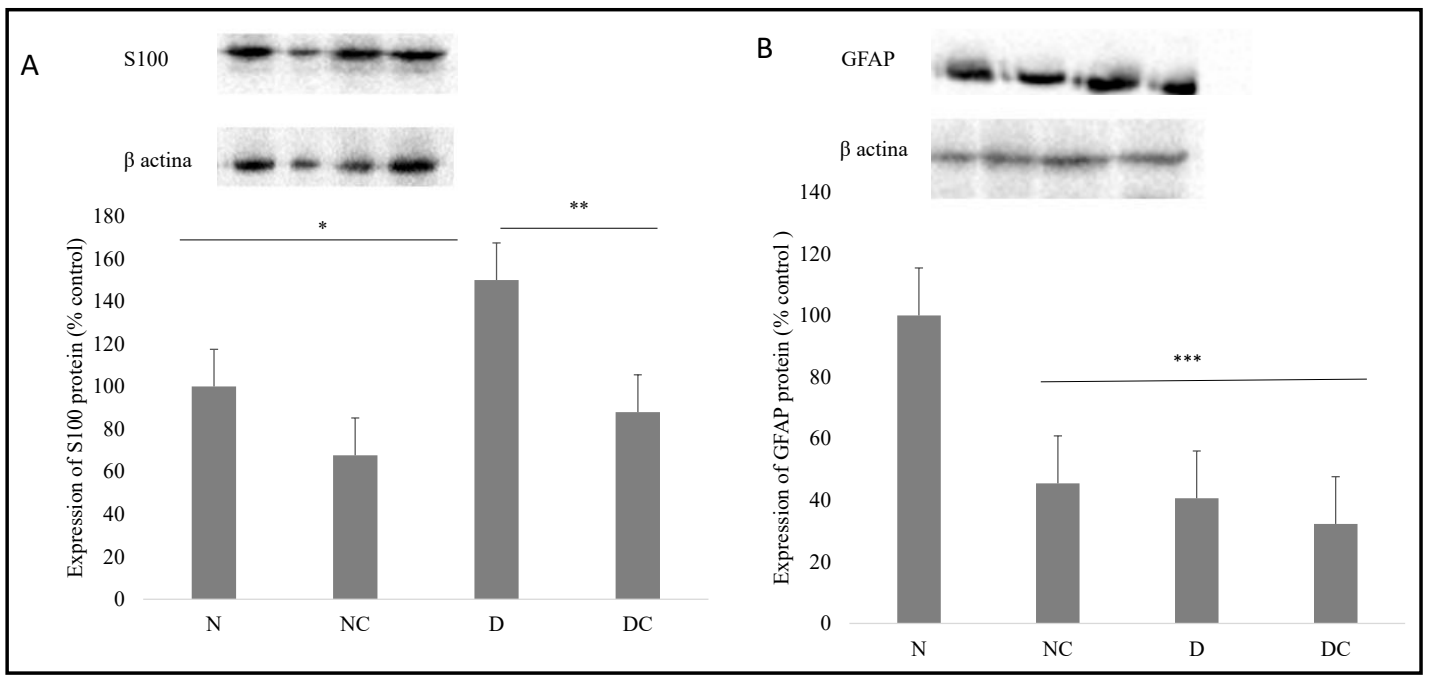

Fig. 3. (A, B) Expression of S100 protein and representative Western blot band (A) and expression of GFAP protein and representative Western blot band (B) in the N, NC, D, and DC groups. The results are expressed as mean \pm SEM. $\mathrm{n}=4$ rats/group. ${ }^{*} \mathrm{p}<0.05$, D group compared with $\mathrm{N}$ group; $\mathrm{p}<0.05$, D group compared with DC group; ${ }^{+} \mathrm{p}<0.0003, \mathrm{NC}, \mathrm{D}$, and DC groups compared with N group.

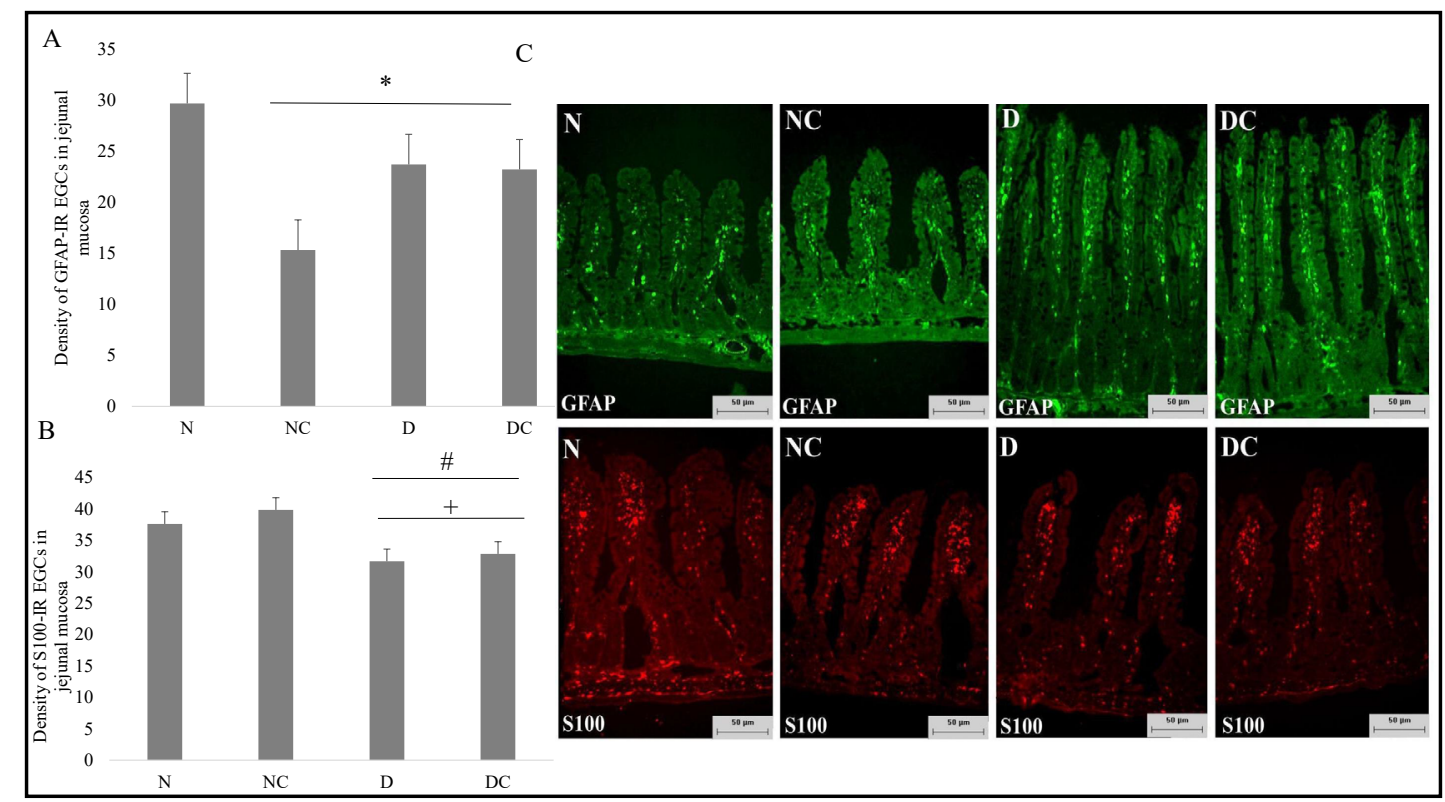

Fig. 4. (A, B) Mean density of GFAP-IR EGCs (A) and S100-IR EGCs (B) per villus in the jejunal mucosa. (C) Representative photomicrographs of GFAP and S100 protein immunostaining in the jejunal mucosa in the $\mathrm{N}, \mathrm{NC}, \mathrm{D}$, and DC groups. Scale bar $=50 \mu \mathrm{m}$. The results are expressed as mean \pm SEM. $\mathrm{n}=6$ rats $/$ group. ${ }^{*} \mathrm{p}<0.001$, compared with $\mathrm{N}$ group; ${ }^{*} \mathrm{p}<0.02$, D and DC groups compared with $\mathrm{N}$ group; ${ }^{+} \mathrm{p}<0.0003, \mathrm{D}$ and DC groups compared with NC group.

The analysis of neuronal density showed an 18\% reduction of HuC/D-IR neurons in the $\mathrm{D}$ group compared with the $\mathrm{N}$ group. This decrease may be attributable to a reduction of antioxidant defense concomitant with the intensification of cellular oxidative stress that resulted from diabetes. According to Kuyvenhoven [27], free radicals can react with DNA, proteins, and lipids, causing neuronal death. Neuronal death that is caused by diabetesrelated oxidative stress is considered a main causal factor for ENS damage [28]. 


\section{Cellular Physiology Cell Physiol Biochem 2019;53:76-86 \\ \begin{tabular}{l|l} 
and BiOchemistry Published online: 14 June 2019 & $\begin{array}{l}\text { DO } 2019 \text { The Author(s). Published by } \\
\text { Cell Physiol Biochem Press GmbH\&Co. KG }\end{array}$
\end{tabular} \\ Do Nascimento Bonato Panizzon et al.: Trichilia Catigua Confers Partial Neuroprotection \\ in the Enteric Nervous System}

In addition to the reduction of HuC/D-IR neurons, we observed a reduction of S100-IR EGCs in the D group compared with the N group. A 26\% reduction of S100 immunoreactivity was observed in the total preparation, with a $16 \%$ reduction of S100 immunoreactivity in the intestinal mucosa. The literature reports various reductions of EGCs that are caused by aging [29] and diet [30]. The reduction of glial cell density in diabetes may also be related to an elevation of oxidative stress. Lopes et al. [13], Qi et al. [11], and Souza et al. [14] reported decreases in glial cell density in the duodenum, stomach, and jejunum, respectively, in diabetic rats. However, other studies by our research group reported different results with regard to glial cell density. This discrepancy may be attributable to the segment that was evaluated, such as the ileum $[18,31]$ and cecum [32]. The impact of diabetes on EGCs varies according to the gastrointestinal segment. Reductions of EGCs and neuronal density are reflected by gastrointestinal tract physiology. Enteric glial cells represent a communication link between the ENS and local immune system, thus playing a role in the normal function of the digestive system [10]. Previous studies suggested that EGCs are the main regulators of intestinal epithelial barrier (IEB) function [33]. The loss of IEB integrity allows the translocation of normally excluded luminal contents (e.g., microorganisms, antigens, and nutrients, among others) to the mucosa, thus initiating and perpetuating inflammatory disorders and tissue injury [34]. The IEB serves as the first defensive boundary between the organism and luminal environment [35]. The reduction of EGCs could be one cause of diarrhea and intestinal constipation, in addition to the low immunity that diabetic patients present.

A previous study evaluated the importance of EGCs in intestinal physiology, showing that all adult rats died within 2 weeks after GFAP-IR EGC depletion because of fulminating jejunileitis [36]. These findings support the role of EGCs in maintaining intestinal integrity. In the present study, we observed a $20 \%$ reduction of GFAP-IR glial cell density in the intestinal mucosa in the $\mathrm{D}$ group compared with the $\mathrm{N}$ group. This may have also been caused by an increase in oxidative stress. The reduction of the density of GFAP-IR EGCs was accompanied by lower GFAP protein expression, evaluated by Western blot. GFAP expression is modulated by glial cells under conditions of differentiation, inflammation, and injury, indicating that the level of GFAP production coincides with the functional status of these cells [10].

The reductions of the density of HuC/D-IR neurons and S100-IR EGCs in the D group were accompanied by increases in the cell body area and S100-IR EGCs, with higher S100 protein expression, evaluated by Western blot. This increase in neuronal area may be attributable to an increase in neurotransmitter synthesis in an attempt to compensate for neuronal death [13]. This increase may also suggest metabolic neural alterations that are caused by diabetes through an increase in sorbitol production, which increases the osmolarity of neurons and causes neuronal edema [7]. The increase in EGCs may reflect cellular edema that is caused by the same metabolic alterations of neurons or a mechanism that compensates for the loss of neurons and seeks to maintain homeostasis. Enteric glial cells provide mechanical support for enteric neurons. They release a wide range of factors that are responsible for the development, survival, and differentiation of peripheral neurons. Enteric glial cells have also been shown to have a more complex nature, playing a role in the maintenance of intestinal homeostasis [12].

Diabetic neuropathy is related to an elevation of ROS. Antioxidants have been used to prevent the development of diabetic neuropathy. The present study used an EAF from $T$. catigua as an antioxidant agent [37]. Longhini et al. [25] found that an EAF from T. catigua contained two flavonoids, procyanidin B2 and epicatechin, which have good antioxidant activity [38]. Administration of the EAF did not alter S100-IR or GFAP-IR EGCs or neuronal density in the DC group, but it prevented the increase in neuronal area of S100-IR EGCs in the DC group. No increase in the area of S100-IR EGCs was found, but a reduction of the expression of the S100 protein was observed, quantified by Western blot. This lack of an increase in cellular area may be attributable to the antioxidant action of the EAF. The antioxidant activity of flavonoids occurs through different mechanisms, such as the elimination of free radicals, 


\section{Cellular Physiology Cell Physiol Biochem 2019;53:76-86

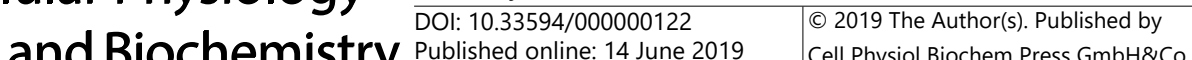 Published online: 14 June 2019 Cell Physiol Biochem Press GmbH\&Co. KG Do Nascimento Bonato Panizzon et al.: Trichilia Catigua Confers Partial Neuroprotection in the Enteric Nervous System}

metal ion chelating agents (e.g., iron and copper), and the inhibition of enzymes that are responsible for the generation of free radicals [39].

Preservation of the densities of S100-IR EGCs and HuC/D-IR neurons were observed in the NC group. The aging process causes ROS generation but to a lesser extent than diabetic individuals that present the activation of different metabolic cascades that converge to produce higher ROS production. In the NC group, the antioxidant action of the EAF protected neurons and EGCs from the deleterious actions of ROS that were generated by the aging process, preserving cell density. Notwithstanding the beneficial effect of the EAF, it altered the cell areas of both neurons and S100-IR EGCs, the density of GFAP-IRs EGCs, and GFAP protein expression. These alterations may indicate that the EAF altered the osmolarity of the cell, causing cellular edema and reducing the density of GFAP-IR cells.

\section{Conclusion}

The effects of additional doses of the EAF on diabetic neuropathy should be evaluated because many treatment responses are dose-dependent. In conclusion, the effects of the EAF from T. catigua were partially beneficial for the prevention of diabetic neuropathy in the ENS.

\section{Acknowledgements}

All authors are grateful to Maria Euride Carlos Cancino, Maria dos Anjos Moreira Fortunato and Maria Ângela Moreira da Costa for technical assistance.

This work was supported by Conselho Nacional de Desenvolvimento Científico e Tecnológico (CNPq) (no477973/2013-2-CNPq) and Coordenação de Aperfeiçoamento de Pessoal de Nível Superior (CAPES).

Cynthia Priscilla do Nascimento Bonato Panizzon performed the experiments, did the statistical analysis and wrote the manuscript. Marcílio Hubner de Miranda Neto, revised the manuscript, Francielle Veiga Ramalho, performed the experiments, Renata Longhini, was in charge of producing the EAF, João Carlos Palazzo de Mello was in charge of producing the EAF and Jacqueline Nelisis Zanoni designed the study, wrote the manuscript and revised the manuscript.

\section{Disclosure Statement}

The authors have no competing interests.

\section{References}

1 Boulton AJM, Vinik AI, Arezzo JC, Bril V, Feldman EL, Freeman R, Malik RA, Maser RE, Sosenko JM, Ziegler D: Diabetic Neuropathies: A statement by the American Diabetes Association. Diabetes Care 2005;28:956962.

2 Cameron NE, Cotter MA, Robertson S: Essential fatty acid diet supplementation. Effects on peripheral nerve and skeletal muscle function and capillarization in streptozocin-induced diabetic rats. Diabetes 1991;40:532-539.

3 Brownlee M: Glycation products and the pathogenesis of diabetic complications. Diabetes Care 1992;15:1835-1843.

4 Cameron NC, Cotter MA: Potential therapeutic approaches to the treatment or prevention of diabetic neuropathy: evidence from experimental studies. Diabet Med 1993;10:593-605.

5 Oates PJ: Polyol pathway and diabetic peripheral neuropathy. Int Rev Neurobiol 2002;50:325-392. 


\section{Cellular Physiology Cell Physiol Biochem 2019;53:76-86 \begin{tabular}{l|l|l}
\hline DOI: 10.33594/000000122 & 2019 The Author(s). Published by
\end{tabular} and BiOChemistry Published online: 14 June $2019 \quad$ Cell Physiol Biochem Press GmbH\&Co. KG \\ in the Enteric Nervous System}

6 Pittenger G, Vinik A: Nerve growth factor and diabetic neuropathy. Exp Diabesity Res 2003;4:271-285.

7 Vincent AM, Russel JW, Low P, Feldman EL: Oxidative Stress in the Pathogenesis of Diabetic Neuropathy. Endocr Rev 2004;25:612-628.

8 Furness, J.B: The Enteric Nervous System. Massachusetts: Blackwell Publishing, 2006.

9 Lomax AE, Fernandez E, Sharkey KA: Plasticity of the enteric nervous system during intestinal inflammation. Neurogastroenterol Mot 2005;17:4-15.

10 Rühl A: Glial cells in the gut. Neurogastroenterol Mot 2005;17:777-790.

11 Qi R, Yang W, Chen J: Role of Enteric Glial Cells in Gastric Motility in Diabetic Rats at Different Stages. J Huazhong Univ Sci Technology Med Sci 2013;3:496-500.

$12 \mathrm{Yu}$ YB, Li YO: Enteric glial cells and their role in the intestinal epitelial barrier. World J Gastroenterol 2014;20:11273-11280.

13 Lopes CR, Ferreira PE, Zanoni JN, Alves AM, Alves EP, Buttow NC: Neuroprotective effect of quercetin on the duodenum enteric nervous system of streptozotocin-induced diabetic rats. Dig Dis Sci 2012;57:3106-3115.

14 Souza SRG, Neto MHM, Perles JVCM, Frez FCV, Zignani I, Ramalho FV, Hermes-Uliana C, Bossolani GDP, Zanoni JN: Antioxidant Effects of the Quercetin in the Jejunal Myenteric Innervation of Diabetic Rats. Front Med (Lausanne) 2017;4:1-8.

15 Tronchini EA, Trevisan AR, Tashima CM, Pereira RVF, Zanoni JN: Supplementation with 0.1\% and 2\% vitamin $\mathrm{E}$ in diabetic rats: analysis of myenteric neurons immunostained for myosin-V and nNOS in the jejunum. Arq Gastroenterol 2012;49:284-290.

16 Hermes-Uliana C, Panizzon CPNB, Trevizan AR, Sehaber CC, Ramalho FV, Martins H A, Zanoni JN: Is L-Glutathione More Effective Than L-Glutamine in Preventing Enteric Diabetic Neuropathy? Dig Dis Sci 2014;59:937-948.

17 Tashima, CM, Hermes-Uliana C, Perles JVCM, Neto MHM, Zanoni JN: Vitamins C and E (ascorbate/tocopherol) provide synergistic neuroprotection in the jejunum in experimental diabetes. Pathophysiology 2015;22:241-248.

18 Panizzon CPNB, Zanoni JN, Hermes-Uliana C, Trevizan AR, Sehaber CC, Pereira RVF, Linden DR, Neto MHM: Desired and side effects of the supplementation with l-glutamine and l-glutathione in enteric glia of diabetic rats. Acta Histochem 2016;118:625-631.

19 Chassot JM, Longhini R, Gazarini L, Mello JC, de Oviveira RM: Preclinical evaluation of Trichilia catigua extracts onthe central nervous system of mice. J Ethnopharmacol 2011;137:1143-1148.

20 Li X, Wang L, Gao X, Li G, Cao H, Song D, Cai S, Liang T, Zhang B, Du G: Mechanisms of Protective Effect of Ramulus Mori Polysaccharides on Renal Injury in High-Fat Diet/Streptozotocin-Induced Diabetic Rats. Cell Physiol Biochem 2015;37:2125-2134.

21 Qiang G, Yang X, Shi L, Zhang H, Chen B, Zhao Y, Zu M, Zhou D, Guo J, Yang H, Zhang L, Du G: Antidiabetic Effect of Salvianolic Acid A on Diabetic Animal Models via AMPK Activation and Mitochondrial Regulation. Cell Physiol Biochem 2015;36:395-408.

22 Chen T, Zheng LY, Xiao W, Gui D, Wang X, Wang N: Emodin ameliorates high glucose induced-podocyte epithelial-mesenchymal transition in-vitro and in-vivo. Cell Physiol Biochem 2015;35:1425-1436.

23 Dos Santos AH, Ramos AC, Silveira KM, Kiss AC, Longhini R, Diniz A, de Mello JC, Gerardin DC: The exposure to Trichilia catigua (catuaba) crude extract impairs fertility of adult female rats but does not cause reproductive damage to male offspring. J Ethnopharmacol 2015;166:86-91.

24 Gomes RM, de Paulo LF, Bonato Panizzon CPDN, Never CQ Cordeiro BC, Zanoni JN, Francisco FA Piovan S, de Freitas Mathias PC, Longhini R, de Mello JCP, de Oliveira JC, Pedrino GR, da Silva Reis AA, Cecchini AL, Marçal MR: Anti-Diabetic Effects of the Ethyl-Acetate Fraction of Trichilia catigua in StreptozotocinInduced Type 1 Diabetic Rats. Cell Physiol Biochem 2017;42:1087-1097.

25 Longhini R, Klein T, Bruschi ML, da Silva WV, Jr., Rodrigues J, Lopes NP, de Mello JC: Development and validation studies for determination of phenylpropanoid-substituted flavan-3-ols in semipurified extract of Trichilia catigua by high-performance liquid chromatography with photodiode array detection. J Sep Sci 2013;36:1247-1254.

26 Stefanini M, De Martino C, Zamboni L: Fixation of ejaculated spermatozoa for electron microscopy. Nature. 1967;216:173-174.

27 Kuyvenhoven J, Meinders A: Oxidative stress and diabetes mellitus: pathogenesis of long-term complications. Eur J Intern Med 1999;10:9-19. 


\section{Cellular Physiology Cell Physiol Biochem 2019;53:76-86

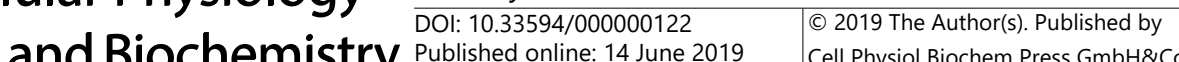

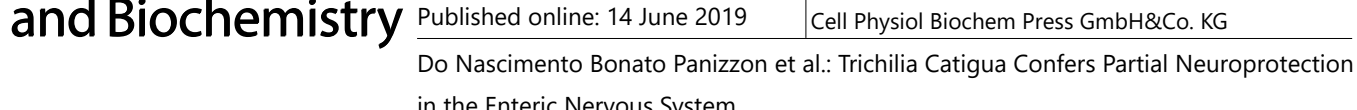

28 Kashyap P, Farrugia G: Oxidative stress: key player in gastrointestinal complications of diabetes. Neurogastroenterol Motil 2011;23:111-114.

29 Phillips RJ, Kieffer EJ, Powley TL: Loss of glia and neurons in the myenteric plexus of the aged Fischer 344 rat. Anat Embryol 2004;209:19-30.

30 Baudry C, Reichardt F, Marchix J, Bado A, Schemann M, des Varannes SB, Neunlist M, Moriez R: Dietinduced obesity has neuroprotective effects in murine gastric enteric nervous system: involvement of leptin and glial cell line-derived neurotrophic factor. J Physiol 2012;590:533-544.

31 Pereira, RVF, Linden DR, Neto MHM, Zanoni, JN: Differential effects in CGRPergic, nitrergic, and VIPergic myenteric innervation in diabetic rats supplemented with $\%$ L-glutamine. An Acad Bras de Cienc. 2016;88:609-622.

32 Ferreira PE, Lopes CR, Alves AM, Alves ÉP, Linden DR, Zanoni JN, Buttow NC: Diabetic neuropathy: an evaluation of the use of quercetin in the cecum of rats. World J Gastroenterol 2013;38:6416-6426.

33 Savidge TC, Sofroniew MV, Neunlist M: Starring roles for astroglia in barrier pathologies of gut and brain. Lab Invest 2007;87:731-736.

34 Buhner S, Buning C, Genschel J, Kling K, Herrmann D, Dignass A, Kuechler I, Krueger S, Schmidt HH, Lochs $\mathrm{H}$ : Genetic basis for increased intestinal permeability in families with Crohn's disease: role of CARD15 3020insC mutation? Gut 2006;55:342-347.

35 Arrieta MC, Bistritz L, Meddings JB: Alterations in intestinal permeability. Gut 2006;55:1512-1520.

36 Bush TG, Savidge TC, Freeman TC, Cox HJ, Campbell EA, Mucke L, Johnson MH, Sofroniew MV: Fulminant jejuno-ileitis following ablation of enteric glia in adult transgenic mice. Cell 1998;93:189-201.

37 Resende FO, Rodrigues E, Luftmann H, Petereit F, de Mello JCP: Phenylpropanoid substituted flavan-3-ols from Trichilia catigua and their in vitro antioxidative activity. J Braz Chem Soc 2011;22:2087-2093.

38 Liebert M, Licht V, Böam V, Biisch R: Antioxidant properties and total phenolics content of green and black tea under different brewing conditions. Eur Food Res Tecnol 1999;208:217-220.

39 Van Acker SA, Van den Berg DJ, Tromp MN, Griffioen DH, van Bennekom WP, Van der Vijgh WJ, Bast A: Sructural aspects of antioxidant activity of flavonoids. Free Radic Biol Med 1996;20:331-342. 